\title{
Pengamatan histopatologis pulpa gigi M. nemestrina yang terpapar getah J. curcas
}

\author{
Indrya Kirana Mattulada \\ Bagian Konservasi \\ Fakultas Kedokteran Gigi Universitas Padjajaran \\ Bandung, Indonesia
}

\begin{abstract}
Tooth pain can be overcame by analgetics oraly or topically applied in the tooth cavity. One of the topical analgetic is latex of J. Curcas. The purpose of this study was to evaluate the anti inflammation effect of the latex of J. Curcas under histopathologic observation. Twenty two teeth of $M$. Nemestrina were prepared until perforation, then applied the lyophilized latex of J. Curcas into the cavity and covered by temporary filling.Eugenol was used as comparison. Evaluation was carried out after 3, 6 and 24 hours. Monkeys were euthanized and the teeth were extracted. Anti inflammation effect was evaluated under histopathology observation. The result of this study show red blood cells and acute inflammation were found under 3 and 6 hours observation, while odontoblastvacuolization cells and lysis of the blood vessels. The conclusion was chronic inflammation occured might explain pulp pain relieved due to the the chronic condition followed
\end{abstract}

Key words: histopathology of the pulp, latex of jatropha curcas, M. nemestrina.

\begin{abstract}
ABSTRAK
Nyeri gigi diatasi dengan pemberian obat-obat analgesik baik secara oral maupun secara topikal langsung pada kavitas gigi. Salah satu analgetik topikal yang dapat digunakan adalah getah J. Curcas. Tujuan penelitian ini adalah untuk mengetahui efek anti inflamasi pemberian getah J. Curcas terhadap pulpa yang dievalusi dengan pemeriksaan histopatologis. Penelitian dilakukan pada 22 gigi molar M. Nemestrina. Gigi tersebut dipreparasi hingga perforasi, lalu masukkan getah J. Curcas yang telah diliofilisasi ke dalam 11 kavitas, lalu ditutup dengan tumpatan sementara. Sebagai pembanding dimasukkan juga eugenol pada 11 gigi lainnya. Pengamatan dilakukan setelah waktu 3, 6, dan 24 jam. Kera dieutanasi kemudian gigi diekstraksi dan dibuat sediaan histopatologis. Pewarnaan menggunakan hematoksilin eosin kemudian sediaan diperiksa di bawah mikroskop cahaya. Hasil menunjukkan pada pengamatan 3 dan 6 jam ditemukan sel-sel darah merah dan sel radang akut. Sedangkan pada pengamatan 24 jam terjadi vakuolisasi sel odontoblast dan lisis pembuluh darah. Kesimpulan penelitian ini adalah terjadinya inflamasi kronis pada pulpa menjelaskan berkurangnya rasa nyeri pada pulpa karena keadaan beralih ke keadaan kronis.
\end{abstract}

Kata kunci: histopatologi pulpa, getah jarak pagar, M. nemestrina

Koresponden: Indrya Kirana Mattulada, Komp BBPP Kayu Ambon, Jl. Maribaya 102, Lembang, Bandung, Indonesia. 


\section{PENDAHULUAN}

Terbukanya kamar pulpa baik oleh karena proses karies atau karena trauma akan menimbulkan rasa nyeri atau sakit yang selanjutnya menyebabkan peradangan. Untuk mengatasi rasa nyeri biasanya diatasi dengan pemberian obat-obat analgetik, baik secara oral maupun secara topikal langsung pada gigi. Salah satu alternative topikal analgetik yang sering digunakan oleh masyarakat awam adalah dengan memasukkan getah J. curcas (jarak pagar) langsung ke dalam kavitas.

Jatropha curcas merupakan tanaman perdu yang mempunyai getah berwarna putih dan agak keruh. Getahnya biasa digunakan sebagai obat kumur pada kelainan gusi berdarah. ${ }^{1,2}$ Diketahui bahwa getah J. Curcas mempunyai rasa pahit yang sejuk namun beracun. Getah tersebut melancarkan darah, menghilangkan bengkak, menghentikan perdarahan serta menghilangkan gatal. ${ }^{2}$ Dari skrining fitokimia yang dilakukan Siregar, ${ }^{3}$ ternyata getah J. Curcas mengandung antara lain sterol atau triterpen, aglikon flavon, tanin, senyawa pereduksi, glikosida steroid, poliose dan saponin. Senyawa tanin dapat menyebabkan presipitasi protein, sedangkan saponin dapat mempengaruhi sel dan dapat menyebabkan hemolisis. Sifat getah yang asam dapat mempengaruhi kelarutan komponen jaringan keras gigi.

Penelitian mengenai perubahan ultrastruktur pada odontoblas dan peradangan jaringan sekitarnya setelah pengasahan gigi molar tikus telah dipelajari secara detail. ${ }^{4}$ Hasilnya memperlihatkan terjadinya serangkaian reaksi pulpa mulai dari respons segera (15-60 menit), hingga terjadinya nekrosis setelah 12-24 jam, termasuk perpindahan nukleus odontoblas ke dalam tubulus dentinalis dan menyebabkan gangguan pada jaringan subodontoblas. Enam jam setelah operasi terlihat perubahan inflamasi dengan adanya destruksi pembuluh darah, leukosit dan eksudat. Perubahan degenerasi mendominasi lapisan odontoblas yang sisa termasuk retikulum endoplasmik yang kasar dan berdilatasi serta mitokondria membengkak. Selain itu juga terlihat kemunduran sel subodontoblastik. Setelah 12-24 jam, perubahan makin meluas dan terjadi nekrosis. Selanjutnya terjadi fagositosis aktif pada tepi antara jaringan vital dan nekrotik.

Heide dan $\mathrm{Mjör}^{5}$ meneliti reaksi pulpa gigi hewan kera dewasa muda yang dipreparasi hingga perforasi dan berhubungan dengan lingkungan mulut pada berbagai satuan waktu. Pada pengamatan 2-4 jam setelah preparasi, memperlihatkan adanya perdarahan ringan. Selain itu perpindahan nukleus odontoblas ke dalam tubulus dentinalis hampir tidak terlihat. Di lain pihak, lapisan odontoblas yang berhubungan dengan tubulus, yang terbuka karena pengasahan berkurang dan odontoblas kadang tidak tampak pada daerah yang berdekatan dengan perforasi. Juga terlihat pemisahan jaringan pulpa dari predentin yang terbatas pada tubulus yang terbuka. Namun demikian belum ada informasi mengenai reaksi pulpa terhadap pemberian analgesik topikal.

Karya ilmiah bertujuan untuk memaparkan hasil penelitian yang dilakukan untuk mengetahui gambaran histopatologis reaksi pulpa terhadap pemberian getah J. curcas secara topikal pada gigi M. nemestrina dengan menggunakan larutan eugenol sebagai bahan pembanding

\section{BAHAN DAN METODE}

Penelitian dilakukan pada 22 gigi molar permanen hewan $M$. nemestrina yang berusia 2-4 tahun dengan BB 3-6 kg. Hewan kera tersebut dirumahkan 24 jam sebelum proses penelitian dimulai. Protokol dan izin penelitian diperoleh dari Komisi Pengawasan Kesejahteraan dan 
Penggunaan Hewan Percobaan Pusat Studi Satwa Primata, Lembaga Penelitian Institut Pertanian Bogor, Bogor.

Hewan uji dianastesi umum dengan injeksi i.m. ketamil $10 \mathrm{mg} / \mathrm{Kg}$ BB (Troy Laboratories, Australia). Hipersalivasi diatasi dengan pemberian atropin sulfas (Ethica, Jakarta) secara i.m. 0,05 $\mathrm{mg} / \mathrm{Kg}$ BB. Selanjutnya dilakukan preparasi gigi dengan menggunakan bur intan berujung bulat \#1 pada kecepatan tinggi tanpa air pendingin di bagian oklusal hingga perforasi. Gigi dibiarkan terbuka dalam lingkungan mulut selama 60 menit. Setelah 60 menit gigi kemudian diisolasi di bagian bukal dan lingual, dan dilakukan disinfeksi dengan povidone iodine (Betadine, Mahakam Jakarta). Tetesi butiran kapas steril dengan masing-masing larutan getah J. curcas 15\% yang telah diliofilisasi dan eugenol (Camex, Germany), masing-masing sebanyak 1 tetes $(0,1 \mathrm{ml})$, dan resapkan pada kapas steril lainnya. Selanjutnya butiran kapas dimasukkan ke dalam kavitas kemudian ditutup dengan tumpatan sementara Cavit-G (Espe, France). Untuk kontrol positif dimasukkan kapas kering yang steril kemudian kavitas ditutup tanpa pemberian bahan uji, sedang kontrol negatif diambil dari pulpa gigi yang tidak dipreparasi. Setelah batas waktu 3, 6, dan 24 jam, hewan uji kemudian dieutanasi memakai pentobarbital (Euthal, Jurox, Rutherford NSW). Gigi yang diberi perlakuan kemudian diektraksi, difiksasi dalam larutan glutaraldehid (Merck, Schuchardt, Germany) kemudian dikirim ke Laboratorium Patologi Anatomi Fakultas Kedokteran Universitas Indonesia untuk pembuatan sediaan histopatologi dengan pewarnaan hematoksilin eosin. Evaluasi histologik yang dilakukan di bawah mikroskop cahaya pembesaran x40 memperhatikan adanya perdarahan, perpindahan nukleus odontoblas, vakuolisasi lapisan odontoblas dan infiltrasi sel radang ke lapisan odontoblas dan jaringan pulpa. $^{5}$

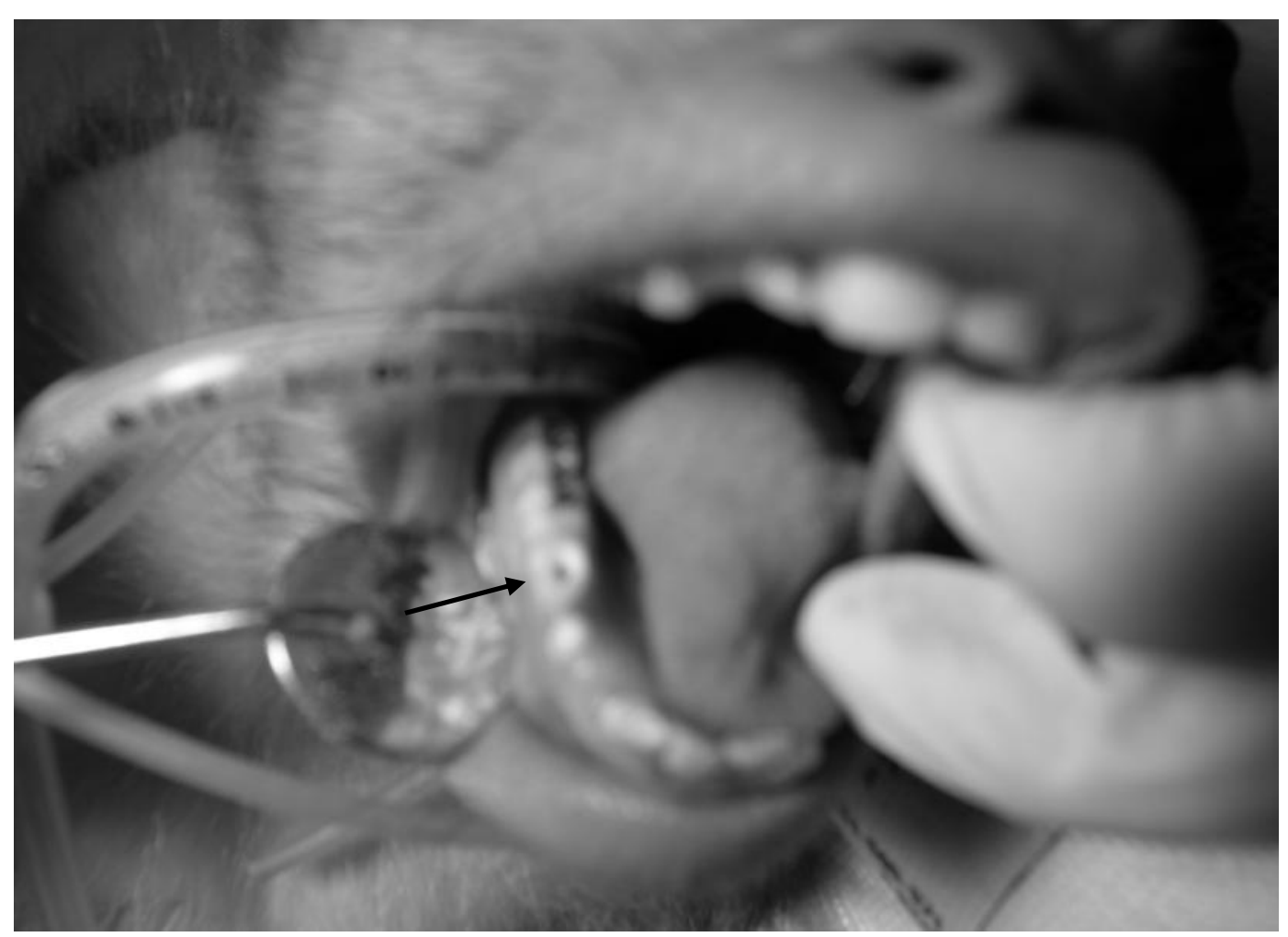

Gambar 1. Tanda panah menunjukkan gigi m. Nemestrina yang telah dipreparasi 


\section{HASIL PENELITIAN}

Dari hasil pengamatan 3 jam, baik pada pulpa yang diberi getah Jatropha.curcas maupun eugenol, terlihat adanya sel radang akut dan selsel eritrosit. Khusus pada pulpa gigi yang diberikan eugenol tampak terjadi vakuol-vakuol sel odontoblas, sedangkan pada pemberian getah J. curcas belum tampak adanya vakuol. Adanya sel eritrosit terjadi akibat proses pengeboran gigi

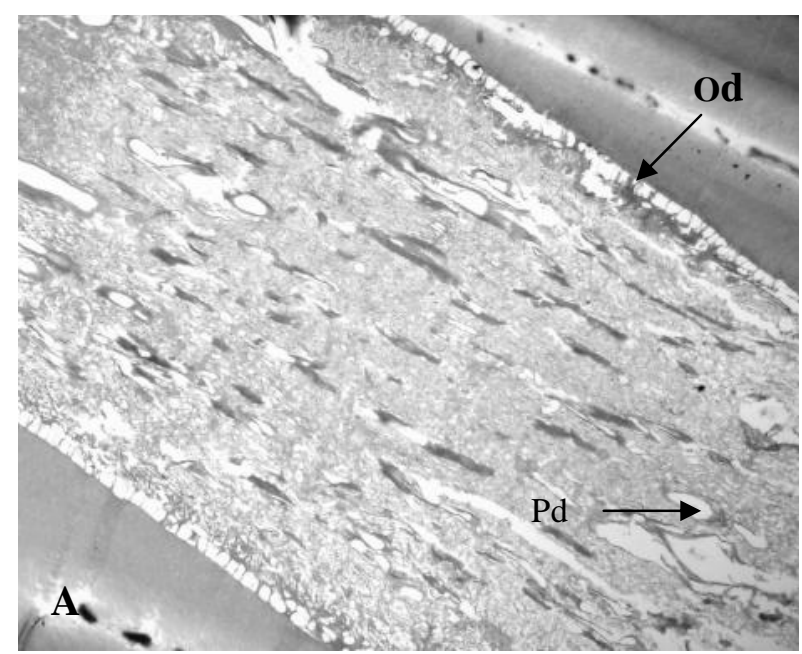

hingga perforasi untuk simulasi trauma hingga terjadinya radang pulpa. Pada pengamatan 6 jam, gambaran yang diperlihatkan hampir sama dengan saat pengamatan 3 jam, hanya saja sel-sel radang tampaknya lebih banyak. Pada pengamatan 24 jam, tampak adanya perdarahan di semua kelompok perlakuan, sedang sel-sel PMN dan lisis terlihat pada kelompok J. curcas pengamatan 24 jam.

Gambar 2. Memperlihatkan pulpa normal pada gigi yang tidak dipreparasi (A) Od=odontoblast, $\mathrm{Pd}=$ pembuluh darah dan pulpa yang dipreparasi tanpa pemberian bahan uji.(B), tampak vakuolisasi. Vac=vakuolisasi. eri $=$ sel darah merah.$($ Pewarnaan HE, pembesaran $\mathrm{x} 10)$
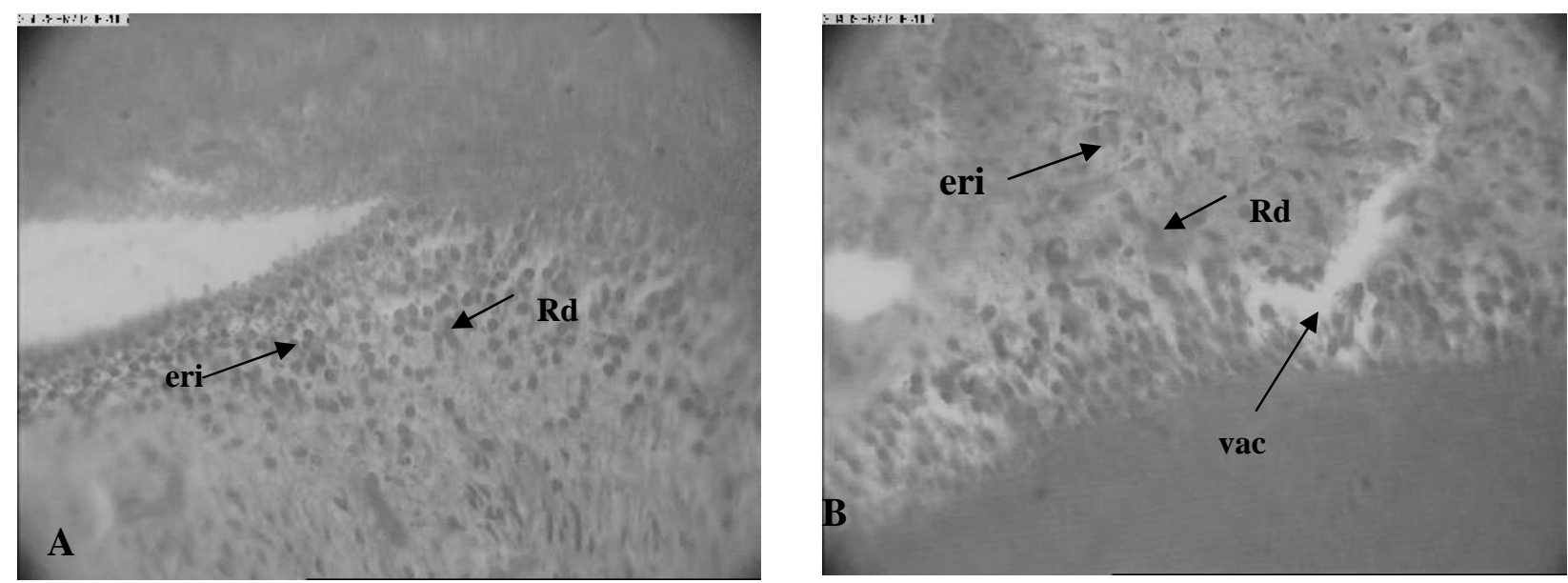

Gambar 3. Pengamatan 3 jam pulpa yang diberi J. curcas $15 \%$ (A), tampak adanya sek radang akut dan eritrosit, serta pulpa yang diberi eugenol (B), selain sel radang dan eritrosit juga ada vakuolisasi. $\mathrm{RD}=$ sel radang, eri=eritrosit, vac=vakuolisasi (Pewarnaan HE, pembesaran $\mathrm{x} 10)$ 

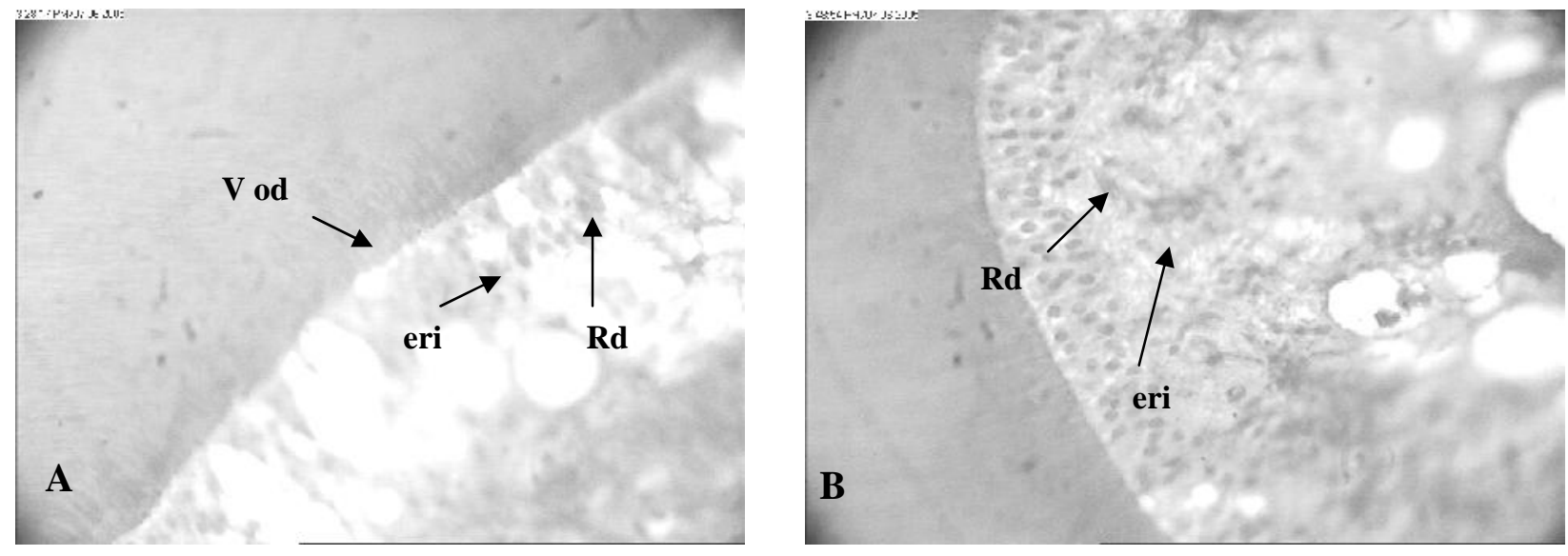

Gambar 4. Pengamatan 6 jam pulpa yang diberi J. curcas 15\% (A) dan eugenol (B).V od=vakuolisasi odontoblast, $\mathrm{Rd}=$ sel radang. Eri=eritrosit (Pewarnaan $\mathrm{HE}$, pembesaran $\mathrm{x} 40$ ).
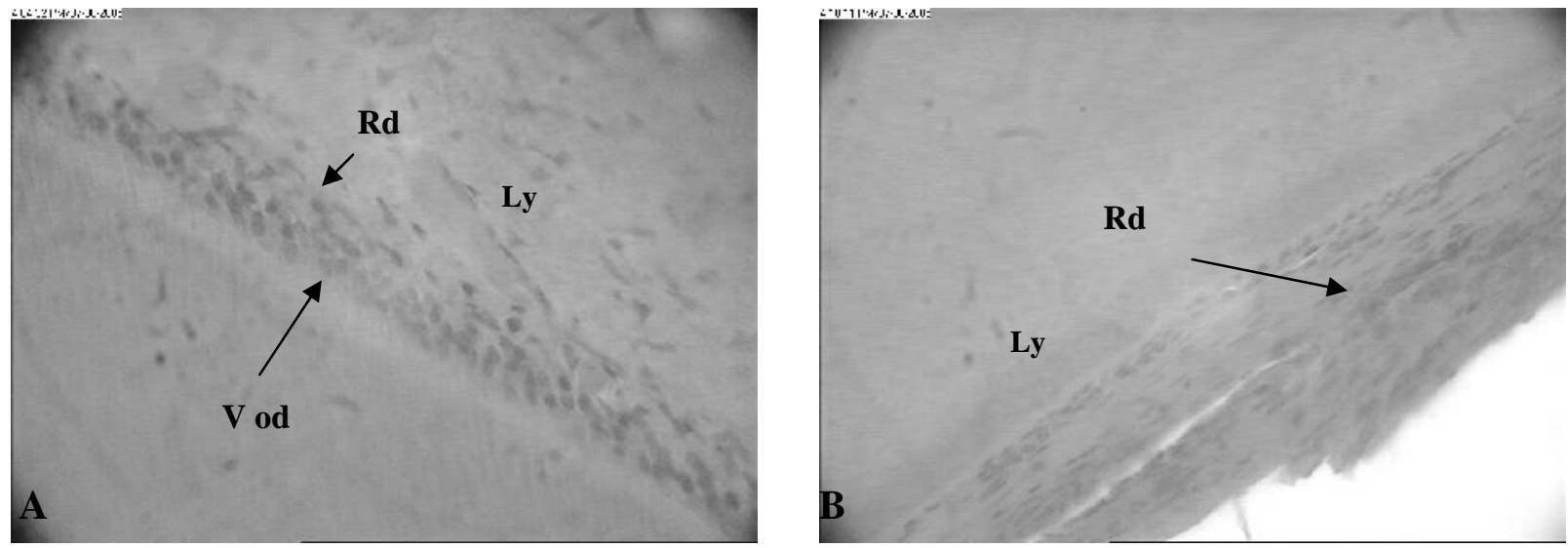

Gambar 5. Pengamatan 24 jam pulpa yang diberi J. curcas 15\% (A) dan eugenol (B). Tampak sel radang kronis, vakuolisasi odontoblast dan lysis pembuluh darah. $\mathrm{Rd}=\mathrm{sel}$ radang kronis, V od=vakuolisasi sel odontoblast, ly=lysis (Pewarnaan HE, pembesaran $\mathrm{x} 40$ ).

\section{DISKUSI}

Inflamasi adalah reaksi jaringan terhadap jejas. Aksi langsung terhadap agen yang merusak memerlukan mobilisasi dan koordinasi vaskuler, neurologik, seluler, dan respons humoral. Tujuan dari proses inflamasi adalah menghancurkan iritan pada sisi jejas, menetralisir sementara dengan cara dilusi atau menahan sambil menunggu tibanya sel-sel pertahanan, dan mempersiapkan perbaikan jaringan yang telah rusak. $^{6}$
Pada penelitian ini terjadi proses inflamasi pulpa akibat preparasi gigi hingga terjadi perforasi, yang kemudian diaplikasikan secara topikal J. Curcas $15 \%$ dan eugenol dengan tujuan untuk menghilangkan nyeri yang timbul. Akibat inflamasi terlihat adanya sel-sel radang akut pada pengamatan 3 jam yang kemudian berubah menjadi sel radang kronis dan nekrosis pada pengamatan 24 jam. Reaksi radang dan nekrosis yang terjadi adalah sebagai akibat tindakan operatif yang dilakukan terhadap 
pulpa. Hal ini sesuai dengan penemuan Siregar yang mendapatkan bahwa ternyata getah hanya menyebabkan nekrosis pada jarak tertentu dari permukaan.

Dari hasil penelitian yang dilakukan Mattulada, ${ }^{7}$ diketahui bahwa ternyata dengan pemberian getah J. curcas, nyeri pulpa dapat dikurangi. Hal ini terjadi karena getah J. Curcas terbukti dapat menghambat prostaglandin $\mathrm{E}_{2}$ yang merupakan mediator nyeri. Tidak terjadinya rasa sakit pada pemberian getah selain karena menurunnya prostaglandin $\mathrm{E}_{2}$, mungkin karena terjadi nekrosis pada pulpa sehingga fungsi sensoris terhenti. Siregar ${ }^{3}$ yang melakukan penelitian pada pulpa gigi normal $M$. fascicularis mendapatkan bahwa ternyata getah hanya menyebabkan nekrosis pada jarak tertentu dari permukaan. Hal ini berbeda dengan hasil yang ditemukan pada penelitian ini, yaitu nekrosis terjadi lebih jauh, mungkin karena perlakuan preparasi untuk memperoleh keadaan pulpa terbuka yang teinflamasi. Pada keadaan pulpitis kronik terbuka yang ulseratif, keadaan pulpa telah menjadi lunak dan hancur dibanding pulpa yang normal. $^{8}$

Kontak langsung pulpa baik dengan J. curcas maupun eugenol menunjukkan terjadinya vakuola odontoblast. Hal ini sesuai dengan pengamatan 24 jam dari Heide dan Mjör ${ }^{5}$ yang mendapatkan odontoblast tampak menghilang. Pada penelitian ini pengamatan dibatasi hanya sampai 24 jam sehingga tidak terlihat proses penyembuhan yang mungkin terjadi.

\section{SIMPULAN}

Dari penelitian yang melakukan pengamatan histopatologis pada pulpa gigi M. nemestrina yang terpapar getah J. Curcas, dapat disimpulkan bahwa pada pengamatan 3 dan 6 jam memperlihatkan adanya radang akut sedang pengamatan 24 jam beralih kekeadaan kronis, adanya lisis menunjukkan pecahnya pembuluh darah di pulpa yang menyebabkan terjadinya nekrosis pulpa, dan hilangnya/menurunnya rasa sakit mungkin disebabkan karena terjadinya nekrosis pada pulpa.

\section{SARAN}

Dengan hasil penelitian ini, disarankan perlu adanya penelitian selanjutnya mengenai kemungkinan getah J.curcas sebagai bahan devitalisasi pulpa.

\section{DAFTAR PUSTAKA}

1. Heyne K. Tumbuhan berguna Indonesia. Jakarta: Badan Penelitian dan Pengembangan Kehutanan, Departemen Kehutanan; 1987. hal. 1180-2.

2. Wijayakusuma $\mathrm{MH}$, Dalimartha $\mathrm{S}$, Wirian AS. Tanaman berkhasiat obat di Indonesia, jilid 2. Jakarta: Pustaka Kartini; 1997. hal 357.

3. Siregar F. Efek getah jatropha curca (euphorbiaceae) terhadap gigi dan jaringan periapeks. [disertasi]. Jakarta: Program Pascasarjana Universitas Indonesia; 2000.

4. Sveen OB. An ultrastucture study of pulpal response to injury. In: Heyeraas KJ, Sveen OB, Mjör IA. Pulp dentin biology in restorative dentistry, Part 3: Pulpal inflammation and it's sequelae, Quintessence Int 2001; 32: 8, 611-25.

5. Heide S, Mjör IA. Pulp reaction to experimental exposures in young permanent monkey teeth. Int Endod J 1983; 16:11-9.

6. Smulson MH, Sieraski SM. Histopathology and Disease of the dental pulp. In: Weine FS. Endodontic therapy, 5th ed. St Louis: Mosby; 2004. p. 149.

7. Mattulada IK. Kajian prostaglandin E2 pada radang pulpa akibat aplikasi getah jarak pagar (jatropha curcas L) serta pengaruhnya terhadap jaringan keras gigi [disertasi]. Makassar: Program Pascasarjana Universitas Hasanuddin; 2005. 
8. Soerono Akbar SM. Pengaruh pembuangan jaringan pulpa dan jaringan periapikal yang terinfeksi pada kesembuhan biologik perawatan endodontik konvensional. Dalam:
Siregar F. Efek getah jatropha curca (euphorbiaceae) terhadap gigi dan jaringan periapeks [disertasi]. Jakarta: Program Pascasarjana Universitas Indonesia; 2000. 